\title{
A microscale enzyme experiment based on bacterial gelatinase
}

\author{
Cristina G. Silvestre ${ }^{1} \mathcal{E}$ Maria Cristina R. Ramos ${ }^{1,2 *}$ \\ ${ }^{1}$ Department of Chemistry, College of Science $\mathcal{E}{ }^{2}$ Research Center for the Natural and Applied Sciences \\ University of Santo Tomas, 1015 Manila, Philippines
}

\begin{abstract}
A possible undergraduate microscale experiment for enzymology is presented. In this study, the ability of Serratia marcescens to hydrolyze gelatin is exploited and the amount of hydrolyzed gelatin was measured using the Bradford Assay. Briefly, to study the enzymatic activity of $S$. marcescens secreted-gelatinase, gelatin solution was incubated with an $18^{\text {th }}$ hour supernatant of $S$. marcescens. After incubation, the amount of hydrolyzed gelatin was monitored. The optimal activity of the enzyme was observed at $1 \mathrm{~h}$ incubation time, $1.25 \%(\mathrm{w} / \mathrm{v})$ gelatin as the substrate, $37^{\circ} \mathrm{C}, \mathrm{pH} 6.7 \square$ and $\mathrm{ZnCl}_{2}$ as activator. For the kinetic properties using gelatin as the substrate, the $v_{\max }$ and $\mathrm{K}_{\mathrm{M}}$ of the gelatinase are $0.23(\mathrm{mg} / \mathrm{mL}) \min ^{-1}$ and $10.33 \mathrm{mg} / \mathrm{mL}$, respectively, using the Lineweaver-Burk plot. The inhibitory effects of EDTA and citric acid were also studied. When gelatin is incubated with $S$. marcescens supernatant in the presence of EDTA or citrate, the slopes of the Lineweaver-Burk plots were not altered, and the $\mathrm{K}_{\mathrm{M}}$ and $v_{\max }$ values of the inhibited reactions decreased. This behavior indicates that these substances are uncompetitive inhibitors. A summarized protocol which can be performed in a $3 \mathrm{~h}$ laboratory period when the bacterial supernatant is prepared beforehand is presented in this study. This protocol enables students to learn quantitative determination of protein using Bradford assay at the same time.
\end{abstract}

Keywords: matrix metalloproteinases, gelatinase, enzyme kinetics and inhibition, Lineweaver Burk plot

\section{INTRODUCTION}

Microscale chemistry has generated a great interest due to the benefits that it presents. It involves the downscaling of laboratory experiments to require small volumes of chemicals used and often simple equipment. As a result, it brought about lower expenses for laboratory materials, reduced chemical hazards and practically negligible environmental

*To whom correspondence should be addressed macrramo@yahoo.com pollution [1]. A number of microscale experiments have been developed for general chemistry [2, 3], organic chemistry [4] and analytic chemistry $[5,6]$ laboratory. However, very few experiments have been used in the biochemistry laboratory.

In this paper, a microscale experiment on enzyme kinetics is described, which can be used in a biochemistry laboratory course. Enzymes kinetics is a fundamental topic in the undergraduate biochemistry course, and a laboratory activity contributes to the 
understanding and appreciation of this topic. The most common enzymes used for the undergraduate laboratory experiments are salivary amylase and invertase. However, experiments have also been reported on the kinetics of other enzymes such as papain [7], alkaline phosphatase [8], lactate dehydrogense [9], and carboxylesterase [10]. The choice of enzymes is based on case of availability and cost of the reagents and equipment.

Other than the enzyme systems previously studied, an alternative microscale enzyme experiment for the undergraduate Biochemistry laboratory involves gelatinase, an enzyme secreted by Gram-negative bacteria, Serratia marscescens. The activity of the enzyme is studied by monitoring the hydrolysis of the substrate, gelatin, and the extent of hydrolysis at a fixed point period is measured using Bradford assay. A microscale approach is adopted for the optimization of the conditions for the enzyme assay and for the study of the kinetics of the enzyme reaction.

\section{EXPERIMENTAL}

Materials and reagents. The experiment requires the following materials: gelatin powder, Bradford reagent and bovine serum albumin (BSA). The source of the enzyme is $S$. marscescens, which was supplied as a frozen stock culture.

A drop of frozen stock of $S$. marcescens is placed in $5 \mathrm{~mL}$ nutrient broth and is incubated at $37^{\circ} \mathrm{C}$ for $6 \mathrm{~h}$. The $6^{\text {th }}$ hour inoculum is reinoculated in $5 \mathrm{~mL}$ fresh nutrient broth and was incubated at $37^{\circ} \mathrm{C}$ for $18 \mathrm{~h}$. Then, the $18^{\text {th }}$ hour inoculum is centrifuged for $5 \mathrm{~min}, 12000 \mathrm{rpm}$ at $4^{\circ} \mathrm{C}$ to separate the precipitate from bacterial supernatant. The amount of protein in the supernatant is then measured using Bradford Assay.
Enzyme activity. The gelatinase activity of the bacterial supernatant is determined by incubating gelatin with the $18 \mathrm{~h}$ inoculum of the microorganism. At the end of the incubation period, the remaining gelatin is estimated using Bradford assay.

The Bradford assay measures protein concentration through the colour generated when the protein binds with Coomasie Blue G250. It is carried out in a microplate by adding $207 \mu \mathrm{L}$ of the Bradford reagent to $43 \mu \mathrm{L}$ of the sample or control solution. The reaction mixture is incubated at room temperature for $5 \mathrm{~min}$, and then the absorbance of the solution is measured at $595 \mathrm{~nm}$.

The effect of different factors such as substrate concentration, $\mathrm{pH}$, temperature and presence of activators or inhibitors, on the speed of the enzyme reaction is investigated by preparing in Eppendorf tubes the mixtures enumerated in Table 1. The reaction mixture is incubated for $1 \mathrm{~h}$ (or as indicated) in an Eppendorf Thermomixer. At the end of the incubation period, the Bradford assay is performed on the sample and control. The gelatinase activity is expressed as percent deviation which is calculated through the following equation:

$$
\text { Percent Deviation }=(\mathrm{A}-\mathrm{B}) / \mathrm{A} \times 100
$$

where $\mathrm{A}$ is the amount of gelatin in the control tube, and $\mathrm{B}$ is the amount of gelatin in the sample tube. The amount of gelatin is determined from the calibration curve for the Bradford assay wherein BSA solutions are used as the standard solutions.

Kinetic assay. Four reaction mixtures containing activator $(100 \mathrm{mM} \mathrm{ZnCl})$, buffer (6.7), different concentrations of gelatin, and same concentration of enzyme are prepared as shown in Table 2. As soon as the enzyme is added, $1 \mathrm{~mL}$ aliquot from the reaction mixture is placed in tubes labelled as $0^{\prime}$. These tubes are then immediately placed in boiling water 
Table 1. Composition of the sample and control tubes for the gelatinase assay

\begin{tabular}{|c|c|c|}
\hline $\begin{array}{c}\text { Assay } \\
\text { Substrate Concentration } \\
\left(4 \mathrm{~h}, 600 \mathrm{rpm}, 37^{\circ} \mathrm{C}\right)\end{array}$ & Sample Tubes & Control Tubes \\
\hline $0.5 \%$ & $\begin{array}{c}250 \mu \mathrm{L} \text { Supernatant } \\
700 \mu \mathrm{L} \text { Distilled water } \\
50 \mu \mathrm{L} 10 \% \text { Gelatin }\end{array}$ & $\begin{array}{l}950 \mu \mathrm{L} \text { Distilled water } \\
50 \mu \mathrm{L} 10 \% \text { Gelatin }\end{array}$ \\
\hline $1.5 \%$ & $\begin{array}{c}250 \mu \mathrm{L} \text { Supernatant } \\
625 \mu \mathrm{L} \text { Distilled water } \\
125 \mu \mathrm{L} 10 \% \text { Gelatin }\end{array}$ & $\begin{array}{c}875 \mu \mathrm{L} \text { Distilled water } \\
50 \mu \mathrm{L} 10 \% \text { Gelatin }\end{array}$ \\
\hline $2.5 \%$ & $\begin{array}{c}250 \mu \mathrm{L} \text { Supernatant } \\
500 \mu \mathrm{L} \text { Distilled water } \\
250 \mu \mathrm{L} 10 \% \text { Gelatin }\end{array}$ & $\begin{array}{c}750 \mu \mathrm{L} \text { Distilled water } \\
50 \mu \mathrm{L} 10 \% \text { Gelatin }\end{array}$ \\
\hline $5 \%$ & $\begin{array}{c}250 \mu \mathrm{L} \text { Supernatant } \\
250 \mu \mathrm{L} \text { Distilled water } \\
500 \mu \mathrm{L} 10 \% \text { Gelatin }\end{array}$ & $\begin{array}{c}500 \mu \mathrm{L} \text { Distilled water } \\
50 \mu \mathrm{L} 10 \% \text { Gelatin }\end{array}$ \\
\hline $\begin{array}{l}\text { Incubation Time } \\
\left(600 \mathrm{rpm}, 37^{\circ} \mathrm{C}\right) \\
\text { Time }=1 \mathrm{~h}, 2 \mathrm{~h}, 3 \mathrm{~h}, 4 \mathrm{~h} \\
\end{array}$ & $\begin{array}{c}250 \mu \mathrm{L} \text { Supernatant } \\
700 \mu \mathrm{L} \text { Distilled water } \\
50 \mu \mathrm{L} 10 \% \text { Gelatin }\end{array}$ & $\begin{array}{c}950 \mu \mathrm{L} \text { Distilled water } \\
50 \mu \mathrm{L} 10 \% \text { Gelatin }\end{array}$ \\
\hline $\begin{array}{l}\mathbf{p H} \\
\left(1 \mathrm{~h}, 600 \mathrm{rpm}, 37^{\circ} \mathrm{C}\right) \\
\mathrm{pH}=4,5,6.7,8,9,10\end{array}$ & $\begin{array}{c}250 \mu \mathrm{L} \text { Supernatant } \\
250 \mu \mathrm{L} \text { Buffer } \\
500 \mu \mathrm{L} 1.25 \% \text { Gelatin }\end{array}$ & $\begin{array}{l}500 \mu \mathrm{L} \text { Distilled Water } \\
500 \mu \mathrm{L} 1.25 \% \text { Gelatin }\end{array}$ \\
\hline $\begin{array}{l}\text { Incubation Temperature } \\
(1 \mathrm{~h}, 600 \mathrm{rpm}) \\
\mathrm{T}=0,25,37,60^{\circ} \mathrm{C}\end{array}$ & $\begin{array}{c}250 \mu \mathrm{L} \text { Supernatant } \\
250 \mu \mathrm{L} \text { Buffer } 6.7 \\
500 \mu \mathrm{L} 1.25 \% \text { Gelatin }\end{array}$ & $\begin{array}{l}500 \mu \mathrm{L} \text { Distilled Water } \\
500 \mu \mathrm{L} 1.25 \% \text { Gelatin }\end{array}$ \\
\hline $\begin{array}{l}\text { Activators } \\
\left(1 \mathrm{~h}, 600 \mathrm{rpm}, 37^{\circ} \mathrm{C}\right) \\
\mathrm{MgCl}_{2}, \mathrm{FeCl}_{2}, \mathrm{CaCl}_{2}, \mathrm{ZnCl}_{2}\end{array}$ & $\begin{array}{c}250 \mu \mathrm{L} \text { Supernatant } \\
250 \mu \mathrm{L} \text { Activator } \\
500 \mu \mathrm{L} 1.25 \% \text { Gelatin }\end{array}$ & $\begin{array}{c}250 \mu \mathrm{L} \text { Supernatant } \\
250 \mu \mathrm{L} \text { Distilled Water } \\
500 \mu \mathrm{L} 1.25 \% \text { Gelatin }\end{array}$ \\
\hline
\end{tabular}

Table 2. Compositions of reaction mixtures for uninhibited and inhibited reactions

\begin{tabular}{l|c|c|c|c}
\hline \multirow{2}{*}{ Components of Tubes } & \multicolumn{4}{c}{ Reaction Mixtures } \\
\cline { 2 - 5 } & 1 & 2 & 3 & 4 \\
\hline $100 \mathrm{mM} \mathrm{ZnCL}$ & $2 \mathrm{~mL}$ & $2 \mathrm{~mL}$ & $2 \mathrm{~mL}$ & $2 \mathrm{~mL}$ \\
\hline $1.25 \%(\mathrm{w} / \mathrm{v})$ Gelatin in Buffer & $4 \mathrm{~mL}$ & $4 \mathrm{~mL}$ & $4 \mathrm{~mL}$ & $4 \mathrm{~mL}$ \\
\hline Buffer $(\mathrm{pH} 6.7)$ & 0 & $1 \mathrm{~mL}$ & $2 \mathrm{~mL}$ & $3 \mathrm{~mL}$ \\
\hline Enzyme & $2 \mathrm{~mL}$ & $2 \mathrm{~mL}$ & $2 \mathrm{~mL}$ & $2 \mathrm{~mL}$ \\
\hline Substrate Concentration $(\mu \mathrm{g} / \mathrm{mL})$ & 6.250 & 4.687 & 3.125 & 1.562 \\
\hline
\end{tabular}

for $5 \mathrm{~min}$ to stop the reaction. Then the reaction mixtures are placed in a shaker incubator set at $37^{\circ} \mathrm{C}$. One (1) $\mathrm{mL}$ aliquots are then obtained at intervals $15,30,60,90$ and $120 \mathrm{~min}$.

At each interval, the tubes are placed in boiling water for $5 \mathrm{~min}$. The incubated samples are placed in a 96 well microplate and Bradford reagent is added.
To study the enzyme reaction in the presence of inhibitors, the same components of the reaction mixtures are used except for the $\mathrm{ZnCL}_{2}$ which is replaced by an inhibitor. Two inhibitors can be evaluated: $100 \mathrm{mM}$ Ethylenediaminetetraacetic acid (EDTA) and $100 \mathrm{mM}$ citric acid. The same procedure as that of the uninhibited reaction is followed to determine the Michaelis-Menten constant $\left(\mathrm{K}_{\mathrm{M}}\right)$ 
and maximum velocity $\left(v_{\max }\right)$ for inhibited reaction.

\section{RESULTS AND DISCUSSION}

Protein content of bacterial supernatant. The bacterial supernatant contains the gelatinase, which is secreted by S. marcescens. The enzyme content of this supernatant is estimated through the determination of its protein content through Bradford assay. Figure 1 shows a typical calibration curve obtained for this assay involving standard solutions of BSA standards in the concentration range of 50$500 \mu \mathrm{g} / \mathrm{mL}$. The curve exhibits a good linearity (Pearson correlation coefficient $=0.9836$ ). Based on this curve the protein concentration of bacterial supernatant is estimated to be in the range of $250-350 \mu \mathrm{g} / \mathrm{mL}$.

Gelatinase activity. The gelatinase activity is evaluated through the decrease in the concentration of the substrate gelatin, as measured using the Bradford assay. The control tubes provide a measure of the initial concentration of gelatin, and the decrease in the control due to the enzymatic hydrolysis is expressed as percent deviation.

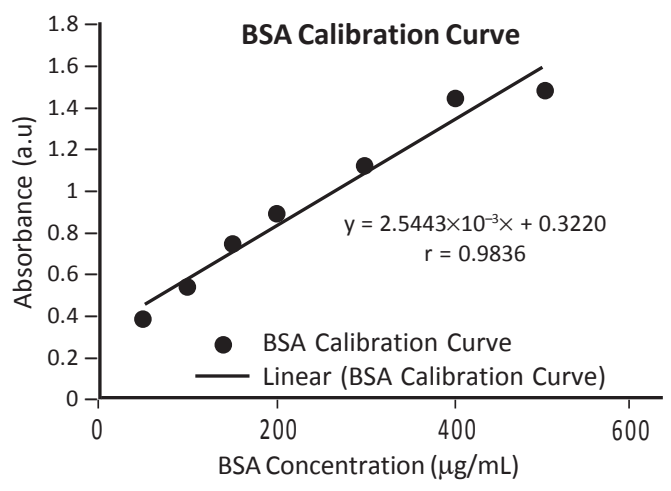

Figure 1. Typical calibration curve for the Bradford assay for the estimation of the protein content of bacterial supernatant
The effect of the different factors on the gelatinase activity of the bacterial inoculum is depicted in Fig. 2. The results indicate an optimum value for each factor wherein the percent deviation is maximum. Under these conditions, the assay for the gelatinase activity will have a high sensitivity. Thus, the measurement of the enzyme activity is conducted on a solution containing $12.5 \%$ gelatin at a $\mathrm{pH}$ of 6.7 and a temperature of $37^{\circ} \mathrm{C}$. The reaction is allowed to take place for a period of $1 \mathrm{~h}$ in the presence of $100 \mathrm{mM} \mathrm{Zn}^{2+}$.

Enzyme kinetics. In this study, the rate of disappearance of gelatin is monitored. The initial velocity for each substrate concentration is determined by plotting the product concentration at different time intervals. The initial velocity is the slope of the linear part of the graph.

The kinetics of enzyme reactions is described mathematically by the Michaelis-Menten equation:

$$
\mathrm{v}=v_{\max }[\mathrm{s}] / \mathrm{K}_{\mathrm{M}}+[\mathrm{S}]
$$

where $\mathrm{v}$ is the initial velocity and $[\mathrm{S}]$ is the substrate concentration. The equation involves two parameters which characterize the enzyme reaction: $v_{\max }$, which is the maximum velocity and $\mathrm{K}_{\mathrm{M}}$ which is known as the MichaelisMenten constant. These parameters can be determined through the Lineweaver-Burk plot, which is based on the linear relationship between the reciprocal of the initial velocity $(1 / v)$ and the reciprocal of the substrate concentration $(1 /[\mathrm{S}])$.

Figure 3 shows the Lineweaver-Burk plot of the results of the enzyme reaction in the presence and absence of two inhibitors, EDTA and citric acid. A linear plot is obtained, indicating that the reaction follows the Michaelis-Menten equation. However, in the presence of EDTA and citric acid, the slope and 

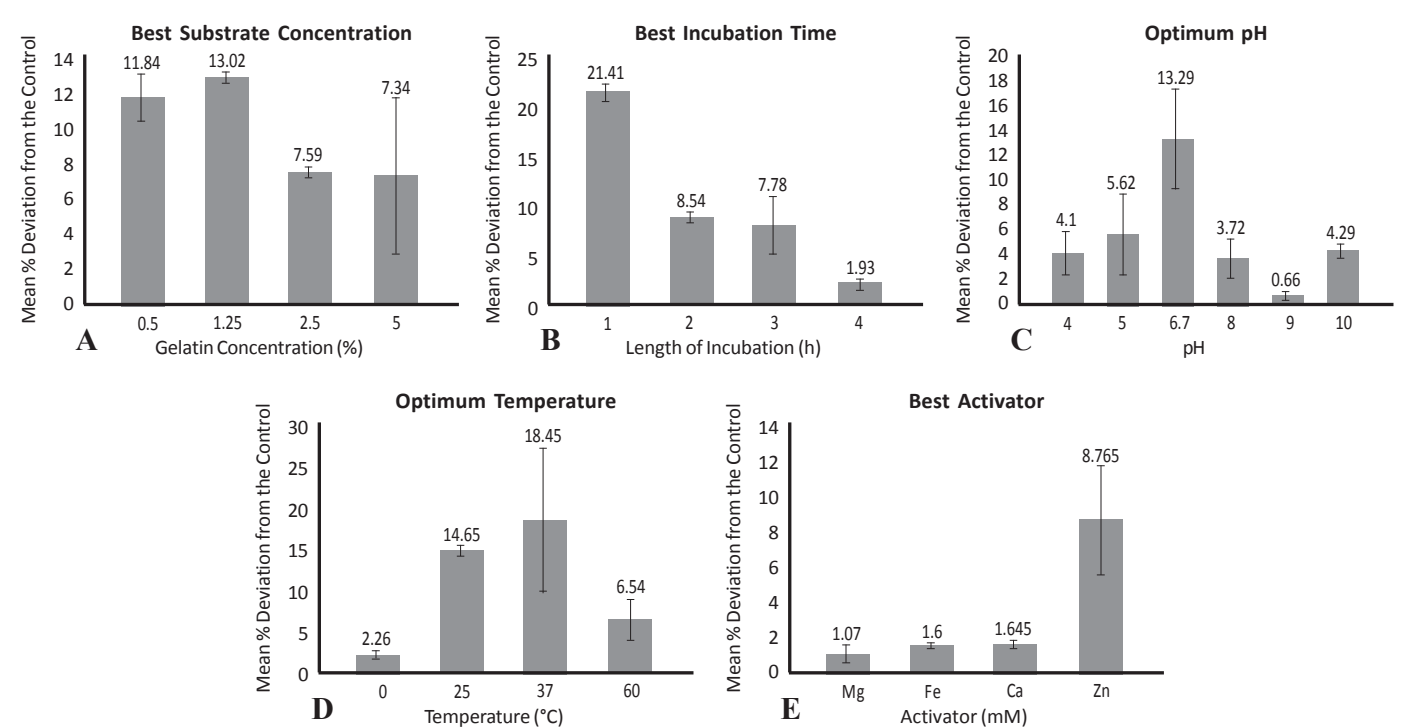

Figure 2. Effect of assay parameters on the enzyme activity: (A) Gelatin Concentration, (B) Reaction Time, (C) pH, (D) Reaction Temperature, and (E) Activator. Results are the mean and standard deviation of three independent trials

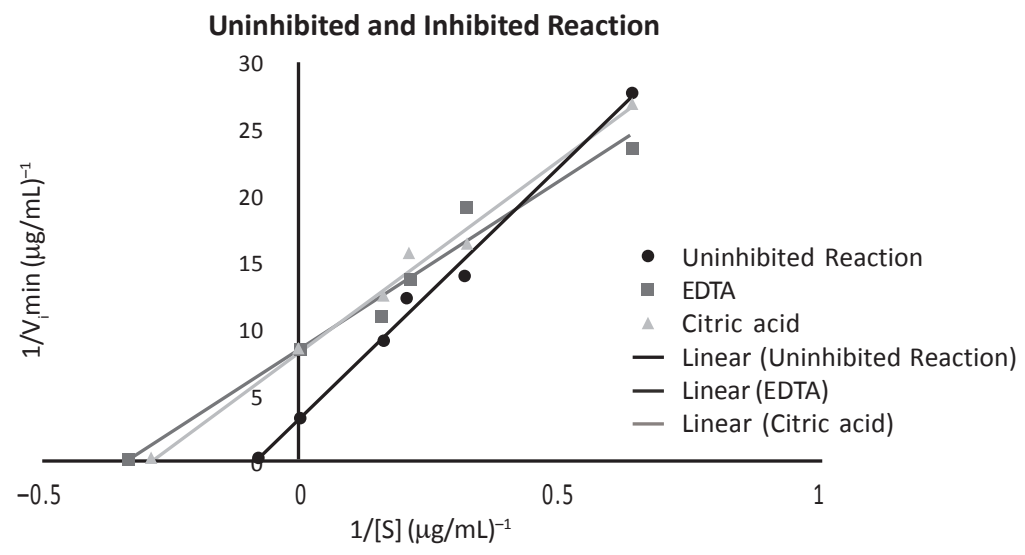

Figure 3. Lineweaver Burk plot for Uninhibited and Inhibited Reaction. Four different substrate concentrations were evaluated with the same concentration of enzyme. Results are mean $+/-$ s.d. of three independent trials.

Table 3. Kinetic properties for uninhibited and inhibited reaction

\begin{tabular}{l|c|c|c}
\hline \multirow{2}{*}{ Kinetic Properties } & \multicolumn{3}{|c}{ Mean \pm SEM" } \\
\cline { 2 - 4 } & Uninhibited & \multicolumn{2}{|c}{ Inhibited Reaction } \\
\cline { 3 - 4 } & Reaction & $100 \mathrm{mM} \mathrm{EDTA}$ & $100 \mathrm{mM}$ Citric Acid \\
\hline $\mathrm{K}_{\mathrm{M}}(\mu \mathrm{g} / \mathrm{mL})$ & $10.33 \pm 3.71$ & $3.03 \pm 0.65$ & $2.27 \pm 0.74$ \\
\hline$V_{\max }(\mu \mathrm{g} / \mathrm{mL}) \mathrm{min}^{-1}$ & $0.23 \pm 0.043$ & $0.15 \pm 0.021$ & $0.11 \pm 0.33$ \\
\hline
\end{tabular}


intercept of the line are changed, and consequently the values of $\mathrm{K}_{\mathrm{M}}$ and $v_{\max }$ are affected. This behavior indicates the uncompetitive inhibition effect of the two inhibitors on the enzyme reaction. As seen from Table 3, the $\mathrm{K}_{\mathrm{M}}$ and $v_{\text {max }}$ values of these two inhibitors are almost the same.

\section{Conclusion}

The microscale experiment presented in this paper yields results which demonstrate the characteristic behavior of enzyme reactions. It requires very small amount and can be completed within a 3-h laboratory period, if the bacterial supernatant is prepared before-hand. Microscale experiments are often used not only for the reason of minimizing wastes but also to lower the cost of the experiment. The enzyme exploited in this experiment is gelatinase, an enzyme which is present in the inoculum of $S$. marcescens. This would definitely lower the cost of the experiment further, since it can be prepared easily in the laboratory.

This system has been performed by the $3^{\text {rd }}$ year Chemistry students. Using the same conditions as indicated in the protocol, the students got similar results. Performing the experiments enhance the skills of the students in the use of micropipettor. After this activity, the students gained the confidence of working with small volumes.

\section{REFERENCES}

[1] Bell B, Bradley J, \& Steenberg E. Chemistry Education through Microscale Experiments. In: Garcia-Martinez J \& Serrano-Torregosa E (Eds.) Chemistry Education: Best Practices, Opportunities and Trends. (J. Wiley \& Sons, 2015).

[2] Szafran Z, Foster JC, \& Pike RM. Microscale General Chemistry Laboratory. (J. Wiley \& Sons, 2002).

[3] Bergantin J, Tan J, \& Sevilla F III. Microscale Experiments for General Chemistry. Kimika 1997; 13:27-31.

[4] Mayo DW, Pike RM, \& Forbes DC. Microscale Organic Laboratory: with Multiple and Multiscale Synthesis. (J. Wiley \& Sons, 2010).

'[5] Bergantin J, Cleofe DRT, \& Sevilla F III. Microscale Experiments Using Low-Cost Conductance Meter, In: Mei-Hung et al. (Eds.) Chemistry Education and Sustainability in the Global Age (Proceedings of the $21^{\text {st }}$ International Conference on Chemical Education). (New York: Springer, 2013).

[6] Gordon J, Harman S, Weiss K, \& Pettegrew B. A Microscale Spectrophotometric Determination of Water Hardness. J. Chem. Educ. 2001; 78:10891090.

[7] Cornely K, Crespo E, Earley M, Kloter R, Levesque A, \& Pickering M. Kinetics of Papain: An introductory biochemistry laboratory experiment. J. Chem. Educ. 1999; 76:644-645.

[8] Dean RL. Kinetic studies with alkaline phosphatase in the presence and absence of inhibitors and divalent cations. Biochem. Mol. Biol. Educ. 2002; 30:401-407.

[9] Powers JL, Kiesman NE, Tran CM, Brown JH, \& Bevilacqua VL. Lactate dehydrogenase kinetics and inhibition using a micropalate reader. Biochem. Mol. Biol. Educ. 2007; 35:287-292.

[10] Nichols CS \& Cromartie TH. Kinetics of carboxylesterase: An experiment for biochemistry and physical chemistry laboratory. J. Chem. Educ. 1979; 56:832-834. 